Georgia State University

ScholarWorks @ Georgia State University

$5-13-2021$

\title{
Rethinking "Disinvestment": Historical geographies of predatory property relations on Chicago's South Side
}

\author{
Rea Zaimi \\ Georgia State University, rzaimi@gsu.edu
}

Follow this and additional works at: https://scholarworks.gsu.edu/urban_studies_institute

Part of the Urban Studies and Planning Commons

\section{Recommended Citation}

Zaimi, Rea, "Rethinking "Disinvestment": Historical geographies of predatory property relations on Chicago's South Side" (2021). USI Publications. 55.

doi: https://doi.org/10.1177/02637758211013041

This Article is brought to you for free and open access by the Urban Studies Institute at ScholarWorks @ Georgia State University. It has been accepted for inclusion in USI Publications by an authorized administrator of ScholarWorks @ Georgia State University. For more information, please contact scholarworks@gsu.edu. 


\title{
Rethinking 'Disinvestment': Historical Geographies of Predatory Property Relations on Chicago's South Side
}

\begin{abstract}
As vacancy in Rust Belt cities becomes a focal point of planning and policy efforts, Chicago planners and private institutions attribute it to "disinvestment" and seek to remove barriers to real estate investment in order to unlock the market's purported ability to bring land to "productive use." Drawing on findings from an analysis of nearly ten thousand postwar property records in the South Side Chicago neighborhood of Englewood, this article demonstrates that vacancy stems not from disinvestment but from predatory and hyperextractive investments in housing that derive economic feasibility and legal sanction from property's historical articulation with race. I argue that racial regimes of ownership are endemic to the operation of real estate markets and function as central modalities for the appropriation of ground rent. As an analytical lens into the political economy of land, racial regimes of ownership expand urban geographers' capacity to address the mechanisms that mobilize difference to accommodate capital's circulation and, more broadly, to account for the racial logics that configure the terrain of contemporary land struggles.
\end{abstract}

Keywords: racial regimes of property, vacancy, disinvestment, ground rent, predation

\section{"Blocks of Inner-City Debris": Toward a Political Economy of the Race Tax}

The "blocks of inner-city debris" in the South Side Chicago neighborhood of Englewood were the focus of an investigative report by Gregory Gordon and Albert Swanson (1976) on the "deterioration of the nation's greatest cities" in December 1976. In rhetorical flourishes reminiscent of Joseph Conrad's Heart of Darkness, the reporters described the stretches of vacant land and buildings in this "black heart of Chicago's sprawling South Side" as "unmistakable symptoms of the cancer that is eating away at the inner city: distrust, disinterest, disinvestment." Remarkably, as they proceeded to expose speculators who abused federal mortgage subsidies for enormous personal gain and insurance companies that charged local homeowners six times the rates of their suburban counterparts, Gordon and Swanson revealed an essential detail about Englewood's socio-economic transformation: driving its decline were not "disinterest" and "disinvestment" but, in fact, predatory interest and lucrative investment in distress. ${ }^{1}$ While this 
detail eluded the reporters, it was not lost on Chicago's working-class Black communities, whose systematic constitution as a captive market made access to anything from food to housing subject to a "race tax" (Satter, 2009; Taylor, 2012; Ture and Hamilton, 1992 [1967]).

Englewood's stretches of vacant land have expanded in the forty-four years since Gordon and Swanson (1976) declared that the neighborhood was "nearing the end of the cycle" yet its vacancy is still understood to result from disinvestment. Vacant lots, the neighborhood's largest land use category, mark $30 \%$ of its landscape - a phenomenon city planners attribute to the fact that "plainly, the market was not interested in Englewood" (Greater Englewood Community Plan, 2008; Woodstock Institute, 2019). "Disinvestment" is capacious. It offers incisive insight into vacancy insofar as it relates the South Side's decline to the post-1970s shift in the allocation of state resources away from life-fostering institutions like health and education toward "deathdealing" (Gilmore, 2002) capacities like policing and incarceration. ${ }^{2}$ This reconfiguration of state functions has left more than half of the households (51\%) in the Englewood area ${ }^{3}$ living below the federal poverty line, $29 \%$ of residents unemployed and, at 60 years, a life expectancy seventeen years below the city's average (Chicago Metropolitan Agency for Planning, 2020a, 2020b). "Disinvestment" is limited, however, in its ability to address the political economy of the race tax and its central role in configuring South Side landscapes. As a narrative animating city planning practice and a concept informing geographers' understanding of uneven development, "disinvestment" treats decline as a function of the absence of capital. Englewood's vacancy, however, stems from the sustained influx of predatory and hyperextractive investment in housing: investment that elucidates the work of race and property in driving the circulation of capital and producing socio-spatial inequalities in US cities.

Property in colonial North America has historically functioned as a "race-making institution" (Bonds, 2018) and race has been a fulcrum for organizing relations of ownership - of land or of one's body - which structure the differential (de)valuation of life, land, and labor that accrues to capital. ${ }^{4}$ As intertwined modalities for creating social difference and channeling it into profit, race and property have developed through related logics of abstraction to provide the ideological basis and material foundations for co-constitutive projects of settler colonialism and racial capitalism. Property's co-production with race in the US has unfolded across legal, economic, scientific, and cultural domains to form what Brenna Bhandar (2018) calls "racial regimes of ownership" (see also Bhandar, 2014; Harris, 1993; Ranganathan, 2016; Safransky, 
2014, 2016). Racial regimes of ownership entered the purview of policy with renewed urgency following the racialized dispossession wrought by the Great Recession, and government responses centered on regulating lending and restoring stagnant housing markets. Yet the decades-long making of Englewood's vacancy reveals that racial regimes of ownership are endemic to real estate markets: property's articulation with race is in fact essential to the operation of markets as infrastructures for rationalizing the appropriation of ground rent.

The institution of private property grants owners monopoly control over land that enables them to appropriate surplus - a value capture that Marx (1991 [1894]: 772) describes in Capital: Volume III as "ground rent," or "the economic form in which landed property is realized." Simply put, ground rent refers to the returns secured from ownership of real property. Geographers working within the political economy tradition emphasize that ground rent configures urban landscapes as it coordinates the circulation of capital (Harvey, 1974, 1982). In his seminal theory of gentrification, Neil Smith (1979) argued that crucial in organizing this circulation is the "rent gap": the difference between the ground rent secured from an existing land use and that which can be potentially realized from a different use. The economic depreciation of neighborhoods, whether propelled by physical deterioration or induced by redlining, causes a parallel decrease in the ground rent realized therein. This incentivizes undermaintenance and a "net outflow of capital" into areas with higher profit rates - that is, disinvestment - until the gap between the ground rent actually realized and that which can be capitalized from a different land use widens enough to incentivize new investment (Smith, 1979: 544). The rent gap thus dictates the flow of capital in and out of urban neighborhoods, driving uneven development and its attendant socio-spatial inequalities.

The history of housing in Englewood over the past seven decades, however, reveals that speculators secured massive returns from real estate in the area despite withholding investment in maintenance. For instance, one investor bought a building for $\$ 16,000$ in 1955 and sold it on contract $^{5}$ to an African American couple for $\$ 27,500$ (172\% markup) five years later, using the revenue from contract installments to pay off a loan for another investment building. After this and a second contract sale were forfeited - inevitably so, considering the exorbitant monthly installments - the building was so deteriorated that the City filed for demolition in 1970. Still, the investor was able to sell it for $\$ 15,500$ later that year, this time to a buyer with a governmentinsured mortgage who had to borrow over $\$ 1,000$ for home improvement within three years before 
defaulting in 1975. This history of predation through property is inscribed on the land in Englewood, where the extraction of ground rent was divorced from physical depreciation and deteriorating buildings were a continuous source of profit throughout the 1960s and 1970s. This uncoupling of physical depreciation from ground rent has been essential for the production of real estate profit on Chicago's South Side yet remains largely uninterrogated by political economy rubrics. While historians have situated the "inner city" as a site of immense profit extracted through evolving predatory mechanisms predicated on the creation of captive housing consumers (Connolly, 2014; George et al., 2019; Taylor, 2019; Ture and Hamilton, 1992 [1967]; Satter, 2009), analyses of ground rent in urban geography continue to treat decline primarily as a function

of abandonment by capital. My study of Englewood's vacancy bridges this lacuna and illuminates the constitutive role of racial regimes of ownership in the appropriation of ground rent and circulation of capital.

In what follows, I examine the dominant narratives informing responses to vacancy in city planning and policy circles, highlighting the firm hold of discourses of disinvestment and market failure on how vacancy is understood. Next, I review the literature on housing segregation in Chicago to provide context for my analysis of the causes of Englewood's vacancy. The findings of this analysis situate vacancy squarely within the historical articulation of race and property that stems, I argue, not from the failure of real estate markets but from the routine operations by which they accommodate capital's circulation in search of rents. In a concluding discussion, I situate racial regimes of ownership as a modality for the appropriation of ground rent and thus as both a condition of possibility for the accumulation of real estate capital and a key analytical category for understanding the geographies of vacancy on Chicago's South Side.

\section{Vacancy in Urban Planning and Policy Imaginaries}

In planning and policy circles, vacancy is understood as an outcome of disinvestment and explained by reference to capital's abandonment of the "inner city." In Chicago, this informs an array of initiatives to remove barriers to real estate investment so as to unlock the market's purported ability to bring land to "productive use": tax-increment financing, land banking, Neighborhood Stabilization Program funding, and tax incentives for Opportunity Zone investments. Driving these efforts is the premise that vacancy stems from "poverty, economic decline, and market failure" (Mallach, 2018: 5) and causes neighborhood distress through 
declining property values, eroding community cohesion (Grodzinski, 2019), and escalating crime (Branas et al., 2016; Branas et al., 2017; Garvin et al., 2013; Kondo et al., 2016). In this view, vacant lots signal a lack of stewardship that "reduces the aesthetic and real value of [surrounding] property" (Sing, 2018) while "undermining the sense of community and discouraging further investments" (Alexander, 2015: 14). Revitalization in turn entails facilitating developers' access to "suitable vacant properties at realistic prices with clear, marketable title" (Mallach, 2018: 5). By positing vacancy as an outcome of market failure, disinvestment narratives uphold the market's presumed primacy as a mechanism for organizing access to land and housing, granting economic and moral sanction to new rounds of commodification.

Where private investment is deemed unviable, side lot programs cast vacant land as a "canvas to empower residents and create a sense of ownership" (O' Keefe, 2018) through gardening and "creative placemaking." While these programs often devolve to residents the costs and responsibilities of land maintenance, they celebrate local involvement in revitalization as an inherent good regardless of its terms and outcomes. "Indeed, the very act of [residents] doing something [with vacant land] is what can compel more attention, resources, and coordination, catalyzing an upward spiral of community investment," proclaims a report by the Center for Community Progress, a leading national resource on vacant land redevelopment (2017: 20). Residents' participation in land revitalization is understood to demonstrate "grit, determination, and ingenuity, and [providing] individuals with the knowledge, appreciation, and language to better participate in future neighborhood development initiatives" (Butcher, 2018).

The community empowerment claims of this approach to revitalization are reinforced by a growing consensus that a deteriorating built environment causes social disintegration. Of particular influence is the green recapitulation of "broken windows" policing logics in a proliferating array of studies on vacancy's correlation with crime (Branas et al., 2016; Branas et al., 2017; Garvin et al., 2013; Kondo et al., 2016). These prescribe physical interventions for problems rooted in unequal social relations, reducing the political-economic forces that configure urban landscapes to matters of land stewardship. Structural violence thus becomes a technical issue remediable through vaguely defined mechanisms like "activating residents" (Sing, 2018) or "boosting neighborhood pride" (Center for Community Progress, 2017: 5). Whether by subsidizing real estate profit or by enrolling residents' unpaid labor in land maintenance, disinvestment as an explanation for vacancy fashions extraction ${ }^{6}$ as development. 


\section{Predatory Property Relations and the Extractive Value of Racism in Chicago}

In Chicago, predatory property relations have been instrumental to realizing what N.D.B. Connolly (2017) calls the "extractive value of racism." Real estate markets have historically generated this value by articulating property with race. The burgeoning real estate industry at the turn of the $20^{\text {th }}$ century secured the credibility and resources necessary for profit by repurposing economic theories that were developed to rationalize US imperialism and that posited private property as a key mechanism in eugenicist projects of "race improvement" (Zaimi, 2020; see also Connolly et al., 2018; Freund, 2007; Taylor, 2019 on eugenics and real estate). Appraisal science integrated these "race improvement" logics into valuation methods to construct markets that routinized the creation of opportunities to maximize real estate profit (Zaimi, 2020; see Howell and Korver-Glenn, 2018, 2020 on present-day discriminatory appraisal). The Home Owners Loan Corporation (HOLC) inscribed the subsequent articulations of race, risk, and value in its mortgage refinancing decisions and codified them in the infamous residential security maps that the Federal Housing Administration (FHA) then adopted to streamline loan underwriting (Freund, 2007; Jackson, 1985; Light, 2011).

FHA underwriting procedures and their adoption by private lenders reinforced African Americans' constitution as captive housing consumers, a feat that was previously accomplished through white vigilante violence, property valuation, racial steering, and restrictive covenants. Their exclusion from housing credit forced Black Chicagoans to access housing through the land installment contract. This made homeownership not only virtually unattainable but also immensely extractive, as it generated profits that filled the pockets of speculators, of the banks financing their operations, and of the individuals who purchased contracts in the secondary market (Coates, 2014; Satter, 2009; Taylor, 2012). In the 1950s and 1960s, contract selling extracted $\$ 3.2-\$ 4$ billion $^{7}$ from Chicago's Black neighborhoods as speculators sold buildings at an average 84\% markup and an effective monthly "race tax" of 142\% (George et al., 2019: 9). Land installment contracts formed the foundations of a thriving economy that was nearly impervious to legislation (Satter, 2009) and derived profit from the socio-material effects of the early- $20^{\text {th }}$ century articulation of race with property.

The Housing and Urban Development (HUD) Act of 1968 promised to disarticulate race from property by guaranteeing mortgages in "declining" and "riot-threatened areas" (Department of Housing and Development [HUD], 1972) and by providing down payment and interest rate 
subsidies for low-income homebuyers. As Keeanga-Yamahtta Taylor (2019) details, however, these programs amounted to little more than African Americans' "predatory inclusion" in the housing market. Without curbing realtors' long-standing practice of locking African Americans out of suburban housing, facilitating access to credit merely enabled speculators to offload virtually uninhabitable buildings onto poor and working-class Black buyers. Low-income homeownership programs revived the profit potential of dilapidated buildings, but this profit hinged on mortgage default. Realtors and mortgage brokers thus targeted poor Black women precisely because of their perceived likelihood of default while HUD blamed the programs' failures on these women's alleged incapacity to own property (Taylor, 2019). New owners struggling to pay inflated mortgages while bringing their homes up to code also bore a disproportionate share of the tax burden. In the 1970s, the effective property tax rate was $10.7 \%$ of market value in Chicago's "blighted" neighborhoods compared to $0.7 \%$ in "upward transitional neighborhoods," and overassessment in predominantly Black neighborhoods ranged from $35 \%$ to $100 \%$ of the county average (HUD, 1973; Lyons et al., 1979 as cited in Kahrl, 2017).

On the South Side in the mid-1970s, the City launched sweeping demolition campaigns to clear the remnants of these predatory property practices, while HUD sold repossessed homes indiscriminately and in bulk, creating new channels for speculation in land and housing. Englewood, whose housing stock attracted an influx of predatory investment as Black residents with restricted housing options began moving into the area in the 1950s, and whose "blocks of inner-city debris" captured Gordon and Swanson's attention forty-four years ago, today has Chicago's second-highest vacancy rate at 30\% (Woodstock Institute, 2019). Though attributed to disinvestment, this vacancy archives the market-induced constitution of property as a site of predation. It is inseparable from the lucrative forms of "investment in distress" (Kahrl, 2017) that derive economic feasibility and legal sanction from Chicago's racial regimes of ownership and constitute working-class Black residents as mere "tenants of capital" (Wyly et al., 2009) and nodes in its ongoing circulation.

\section{Historical Geographies of Vacancy in Englewood}

Urban vacancy became a focal point of planning and policy efforts in Chicago after the Great Recession. In the Chicago metropolitan area, which led the nation in volume of high-cost housing loans during the three years leading up to the recession, the foreclosure crisis was acutely 
felt in South and West Side neighborhoods that were disproportionately targeted with predatory mortgages (The Chicago Reporter, 2012). The Englewood community area had Chicago's highest rate of foreclosure filings between 2006 and 2008, with a sheer 10.5\% of its residential properties entering foreclosure in 2008 alone (Institute for Housing Studies at DePaul University, 2021). Local revitalization efforts have since centered on restoring land and real estate markets through interventions such as land banking and home purchase and rehab assistance grants. One such effort is Large Lots, a program that sells City-owned lots to local property owners at \$1 per parcel. Large Lots is premised on the notion that vacancy can be remedied by streamlining the market for vacant land to reduce the City's landholdings while fostering opportunities for resident-led "creative placemaking" that produces orderly landscapes signaling care and community in neighborhoods historically constructed as chaotic, with implications for these places' potential to attract future real estate investment (personal communication with an officer at the Chicago Department of Planning and Development, March 2018).

While Large Lots' effects exceed the scope of this article, the history of $295^{8}$ of these lots recently sold in Englewood challenges the program's premise that vacancy stems from abandonment by capital and can be equitably addressed by restoring the operation of local land and real estate markets. In what follows, I demonstrate vacancy's basis in racial regimes of ownership by presenting findings from a land history project tracing the postwar history of Englewood's Large Lots. The project from which these findings are drawn is informed by nearly ten thousand property records obtained from the Cook County Recorder of Deeds and the County Clerk: deeds, mortgage and trust deed forms, foreclosure documents, land installment contracts, declarations of contract forfeiture, tax deeds, liens, and tax debt sale records. My analysis focuses on identifying, first, the immediate causes of demolition on each lot and, second, the longer-term processes that precipitated them.

While vacancy drew pronounced planning and policy attention after the 2007 housing crisis, Englewood's vacant lots archive a protracted crisis: one caused not by the failure of real estate markets in the Great Recession but by their routine operation over the past seven decades. The direct causes of vacancy for the buildings examined in this study fall under three categories: code violations resulting from deferred maintenance by speculators, slumlords, or contract sellers (43\%); mortgage foreclosure (29\%); and owners' death $(4 \%) .{ }^{9}$ But these causes are intimately entangled and have emerged from a longer history of predatory selling and lending practices that 
have made housing a site of hyperextraction on Chicago's South Side. In what follows, I narrate part of this history through the stories of three lots.

Though $29 \%$ of the study buildings became vacant as a direct result of mortgage foreclosure, more than one third (35\%) experienced foreclosure one or more times before they became vacant. Mortgage default often came at the tail end of decades of exploitative contract sales and deferred maintenance by slumlords and speculators, as illustrated by one lot that became vacant in the mid-1980s. In this case, in 1965 a realtor sold a dilapidated building on contract for $\$ 12,900$ and then sold the contract to an investor. Given the considerable markup on contracts, selling them to investors in a secondary market for less than the amount owed on them was common and profitable. It enabled speculators to secure a large sum to finance other investments while offering investors a steady revenue stream at a discount (Satter, 2009). The contract buyers actually obtained the deed in 1969, but this was merely two months after the City initiated a demolition case for code violations. Having already paid an exorbitant amount for a deteriorating building, they then had to borrow a total of $\$ 28,000$ through the early 1980 s to finance garage construction, boiler installation, and other renovation projects until this debt exceeded the property value to such an extent that vacating became the only viable option. ${ }^{10}$

This type of "building dumping" became widespread and immensely profitable after the expansion of federal low-income homeownership programs in 1968. Most of the study buildings sold through these programs in the late 1960s and early 1970s were dilapidated at the time of sale. One third of them had for years been held as rental properties under the Illinois Land Trust, a title arrangement that slumlords commonly used precisely because it obscured legal liability for building maintenance by concealing their identities from public records (Haswell and Levine, 1974). Lax federal oversight allowed mortgage companies to collude with realtors in selling these derelict buildings to high-risk buyers through falsified applicant income records and fraudulent appraisals (Bliss and Neubauer, 1975a; Taylor, 2019). Gordon and Swanson (1976) detail the toll of these unscrupulous practices on homebuyers in Englewood. A woman they interviewed paid $\$ 16,500$ for a home her realtor had bought for $\$ 8,500$ four months earlier only to find the heat broken, the stairs collapsing, the carpet rotting, the roof leaking, and the chimney deteriorating repairs amounting to $\$ 2,300$.

By 1975, excessive repairs had forced hundreds of FHA-insured buyers in Chicago to walk away from their homes (Bliss and Neubauer, 1975b). Because investors used homeownership 
programs to offload trust-held properties dilapidated by years of rental and contract sales, $80 \%$ of the buildings in this study that were sold through these programs resulted in foreclosure. Lenders pursued foreclosure on these loans after even as few as two missed payments so as to quickly collect the entire value of a home rather than wait decades for the mortgage to mature - a practice enabled by negligent federal monitoring (Bliss and Neubauer, 1975a). Nearly half of foreclosures among the study buildings sold through federal homeownership programs occurred within five years of sale. One in five were foreclosed within only two years. When repossessed buildings were not demolished, HUD sold them at bids sometimes as low as $\$ 250$ to investors who typically kept them vacant or leased them before walking away or losing them to code violations. By the early 1990s, nearly half (46\%) of the FHA-insured study buildings repossessed by HUD had been sold to speculators. In using government-guaranteed mortgages to dispose of derelict properties, then, investors not only profited on the backs of taxpayers ${ }^{11}$ and working-class Black homebuyers but also created new opportunities for speculation in foreclosure and tax debt markets.

More than one third (36\%) of all demolitions resulting from foreclosure were predatory ${ }^{12}$ purchase or refinance loans. ${ }^{13}$ On one occasion in 1977, after an FHA-insured owner defaulted on a dilapidated building he had bought from a slumlord a few years prior, HUD conveyed the building to a buyer who obtained three rehab loans. In 1998, three years after refinancing one loan under highly predatory terms - a balloon-payment, variable-rate mortgage with a starting interest rate of $13.15 \%$, nearly 5 percentage points above that month's average - the buyer faced foreclosure. The lender then kept the building vacant until the City paid $\$ 9,200$ to demolish it. The loan that precipitated this building's vacancy was part of an aggressive wave of predatory lending in Englewood at the turn of the millennium. Nearly 3 out of 4 (71\%) study buildings that were sold in this period were subject to a predatory mortgage. Even when controlling for income and credit scores, predominantly Black Chicago neighborhoods like Englewood at this time had higher levels of nonprime loans than their white counterparts (Calem et al., 2004; see also Immergluck and Wiles, 1999), and Black Chicagoans with six-figure salaries were more likely to get high-cost loans than whites earning less than $\$ 35,000$ (Kelly, 2007). In 2006 , a sheer $75 \%$ of the mortgages originated in Englewood were high-cost loans (The Chicago Reporter, 2012).

On another occasion in 1955, notorious Chicago slumlord Gerald Crane bought a building for $\$ 6,600$ and sold it on contract to an African American couple for $\$ 12,900$ two months later. The $\$ 115$ monthly contract installments enabled Crane to make payments on two consecutive trust- 
deed loans ${ }^{14}$ for which this building served as collateral. One loan was payable in monthly installments of $\$ 66$ - terms Crane could easily meet with the $\$ 115$ the contract buyers paid him monthly. The "race tax" he charged the contract buyers by selling them the building at nearly $200 \%$ markup enabled him to obtain and pay the loans crucial for expanding his business. In 1961, Crane sold the contract to Jay Goran, an infamous speculator with whom he frequently conducted business. Goran lent the contract buyers $\$ 2,744$ to pay the last few contract installments. This loan enabled him to establish two profit streams from a single contract: one from the interest on the outstanding contract installments; the other from the interest on the $\$ 2,744$ he lent the couple so they could pay those last installments. The couple obtained the deed in August 1962. 17 years later, in June 1979, they sold the building on contract for $\$ 17,000$ but the buyers forfeited within two years. The couple then got a $\$ 11,750$ trust-deed loan at $16 \%$ annual interest $-2.18 \%$ higher than that month's average rate - and used part of the money to fix the roof and the porch. They lost the building to loan default in 1985, and it remained vacant until the City demolished it in 1990.

\section{Racial Regimes of Ownership as Market Modalities for the Appropriation of Ground Rent}

Englewood's vacancy stems not from disinvestment but from lucrative investments in distress: $200 \%$ markups, 13\% mortgage interest rates, $172 \%$ profit on contracts. The nonprime loans, contracts, and land trusts that secured these profits are not illicit housing instruments but standard market mechanisms that, in a context of housing consumers rendered captive through decades of restrictive covenants, racial steering, and redlining, were mobilized to decouple ground rent from physical depreciation and channel social difference into profit. Neither external to real estate markets nor produced by their failure, Englewood's vacancy results from the flexible ways in which markets, as key infrastructures of racial capitalism, instrumentalize the conditions created by systemic racism to generate profit and, through this, articulate race with property in service of accumulation.

Vacancy's basis in racial regimes of ownership reveals the limits of "disinvestment" as a narrative informing city planning and policy efforts to revitalize vacant land on Chicago's South Side. While these efforts focus on restoring the operation of local real estate markets to attract private investment that will bring land to "productive use," Englewood's vacant lots archive a history of predatory investment that challenges the market's presumed primacy as a mechanism 
for organizing access to land and shelter. For decades in Englewood, real estate profit has hinged on the constitution of housing as a site of hyperextraction through the creation of a racialized class of captive housing consumers exploitable by predatory investments. In this context, the use of "disinvestment" narratives in revitalization efforts that boost the availability and profit potential of vacant land to real estate capital appears misguided.

The history of Englewood's vacancy also challenges the notion of "disinvestment" that informs urban geographers' engagements with ground rent. Within the political economy tradition, analyses of the role of ground rent in coordinating capital's circulation and configuring urban landscapes have generated a critical understanding of the social forces that produce uneven urban development. These frameworks' premise that a decrease in ground rent and withdrawal of investment attends the physical depreciation of buildings, however, elides the uncoupling of physical depreciation from ground rent through the market- and policy-driven creation of captive housing consumers. Furthermore, in treating decline as a function of the absence of capital, these frameworks fail to capture the key role of predatory investment in the political economy of real estate. Extant analytical engagements with ground rent thus remain limited in their capacity to account for the constitutive work of race in shaping how ground rent is extracted. The history of Englewood's vacancy illuminates the work of racial regimes of ownership as market modalities for the appropriation of ground rent. As an analytical lens into the urban political economy of land, racial regimes of ownership expand our capacity to address the social and material conditions that enable and structure capital's circulation in search of rents. Viewed from this lens, vacancy appears not as a spatial residue of capital's necessarily uneven distribution across space but a living archive of predatory property relations that produce and mobilize racial difference to subsidize capital's accumulation.

\section{Endnotes}

${ }^{1}$ I borrow the term "investment in distress" from Andrew Kahrl (2017).

${ }^{2}$ While in a fiscal crisis in 2015 , Illinois dedicated $\$ 1.4$ billion to the Department of Corrections - a figure that is increasing despite declining crime rates. On 851 blocks in Chicago in 2005-2009, over $\$ 1$ million/block was spent on incarceration (https://chicagosmilliondollarblocks.com). 38\% of Chicago's operating budget goes to the Police Department. The city's daily spending on policing 
(nearly \$5 million) is the equivalent of what it spends on mental health services in five months, substance abuse treatment in 18 months, and violence prevention programs in 32 months (Ballesteros, 2020).

3 This article reflects local residents' understanding of Englewood's geographical boundaries, which does not distinguish between the community areas of Englewood and West Englewood. I thus refer to the geography comprising these two community areas as "Englewood." The unemployment and poverty statistics provided here account for both community areas.

${ }^{4}$ Lisa Cacho (2011) theorizes gender, race, and other forms of social difference as interconnected modalities of differential (de)valuation that underwrite and naturalize relations of inequality. This understanding is informed by scholarship on racial capitalism and feminist political economy that foregrounds the constitutive role of social difference in surplus accumulation (Robinson, 1983; Federici, 2004; Melamed, 2015; Dawson, 2016; Fraser, 2016; Pulido, 2016).

${ }^{5}$ The land installment contract is a financing arrangement where the buyer acquires no equity until they pay for all or a significant portion of their property. In Chicago in the 1950s and 1960s, investors sold homes on contract at inflated prices and interest rates considerably higher than the FHA interest rate cap of $5.75 \%$. On an Englewood census tract where the median home value in the early 1960 s was $\$ 14,100$ and the median monthly rent $\$ 101$, for example, an investor sold a home on contract in 1961 for $\$ 17,000$. The buyers put down $\$ 1,000$ and paid monthly installments of $\$ 139.39$ at $6.5 \%$ annual interest. They also paid property taxes and insurance even though they would not own the home until $\$ 8,500$ was paid off. The contract buyers thus paid nearly $40 \%$ more than the median rent for an arrangement that, to quote Ta-Nehisi Coates (2014), "combined all the responsibilities of homeownership with all the disadvantages of renting - while offering the benefits of neither."

${ }^{6}$ I use "extraction" to refer broadly to processes of appropriating surplus value from land and labor.

7 April 2019 dollars.

819 of the 314 Large Lots sold in Englewood were excluded due to missing property records.

${ }^{9}$ Direct causes of vacancy could not be established for $24 \%$ of the sample due to insufficient records. Many of these lots, however, experienced foreclosures and deferred maintenance by contract sellers and speculators throughout the study period. 
${ }^{10}$ In 1984, the median house value in this Englewood census tract was \$15,100 (Chicago Fact Book Consortium, 1984).

${ }^{11}$ By 1975, abuses of federal homeownership programs had cost HUD \$42 million in Chicago alone (Bliss and Neubauer, 1975c).

12 In finance, "subprime" loans - issued to borrowers with nonprime credit ratings - are distinct from "predatory" loans, which involve explicit unscrupulous activity. Credit ratings, however, are not neutral representations of creditworthiness. As a knowledge practice, credit risk obscures historically structured inequalities and refashions their outcomes as indicators of individual economic deficiency (see Chakravartty and Da Silva, 2012 on "subprime" as racial signifier). Lenders' well-documented practice of offering subprime mortgages to Black and Latinx borrowers even when they qualified for prime loans further complicates the unstable boundary between "predatory" and "subprime." For this reason, while my analysis relies on a formal definition of "subprime" to identify nonprime mortgages, I refer to them as "predatory" loans.

${ }^{13}$ Because mortgage documents did not list loan fees and did not always disclose the interest rate, this figure is based on a conservative definition of "subprime." First-lien loans whose fixed or minimum interest rate on the month of their origination was at least 1.75 percentage points above the monthly average commitment rate on 30-year fixed-rate mortgages reported by Freddie Mac were identified as subprime (following the definition by the New York Department of Financial Services). This category also includes loans with balloon payments, prepayment penalties, mandatory arbitration clauses, and adjustable interest rates.

${ }^{14}$ In a trust-deed loan, the borrower secures the loan by conveying title to the property to a third party, the trustee, to hold on behalf of the lender. In the case of default, the trustee may bypass the judicial foreclosure process by directly selling the property to recoup the debt owed to the lender.

\section{References}

Bhandar B (2014) Property, law, and race: Modes of abstraction. UC Irvine Law Review 4: 2032018.

Bhandar B (2018) Colonial Lives of Property: Law, Land and Racial Regimes of Ownership. Durham: Duke University Press. 
Bliss G and Neubauer C (1975a) FHA wastes \$4 billion and creates city slums. The Chicago Tribune, 22 June.

Bliss G and Neubauer C (1975b) HUD tries to stop reform. The Chicago Tribune, 2 July.

Bonds A (2018) Race and ethnicity I: Property, race, and the carceral state. Progress in Human Geography 43(3): 574-583.

Branas CC, Kondo MC, Murphy SM, South EC, Polsky D and MacDonald JM (2016) Urban blight remediation as a cost-beneficial solution to firearm violence. American Journal of Public Health 106(12): 2158-2164.

Branas CC, South E, Kondo MC, Hohl BC, Bourgois P, Douglas JW and MacDonald JM (2017) Citywide cluster randomized trial to restore blighted vacant land and its effects on violence, crime, and fear. Proceedings of the National Academy of Sciences of the United States of America 115(12): 2946-2951.

Butcher A (2018) Transforming vacant land into community assets. Shelterforce, 18 November. https://shelterforce.org/2018/11/13/transforming-vacant-land-into-community-assets/ (Accessed on 8 February 2019).

Cacho LM (2011) Racialized hauntings of the devalued dead. In: Hong GK and Ferguson RA (eds) Strange Affinities: The Gender and Sexual Politics of Comparative Racialization. Durham: Duke University Press, pp 25-52.

Calem PS, Gillen K and Wachter S (2004) The neighborhood distribution of subprime mortgage lending. Journal of Real Estate Finance and Economics 29(4): 393-410.

Center for Community Progress (2017) Piloting New Partnership Opportunities between a Land Bank and a Community Land Trust in Albany, New York. Center for Community Progress Report to Albany County Land Bank and Albany Community Land Trust, Washington, DC, June.

Chicago Fact Book Consortium (1984) Local Community Fact Book: Chicago Metropolitan Area: Based on the 1970 and 1980 Censuses. Chicago: Chicago Review Press. Chicago Metropolitan Agency for Planning (2020a) Community Data Snapshot: Englewood, June 2020. Chicago, IL: CMAP.

Chicago Metropolitan Agency for Planning (2020b) Community Data Snapshot: West Englewood, June 2020. Chicago, IL: CMAP. 
Chakravartty P and Ferreira da Silva D (2012) Accumulation, dispossession, and debt: The racial logic of racial capitalism - an introduction. American Quarterly 64(3): 361-385.

Coates T (2014) The case for reparations. The Atlantic (June Issue).

https://www.theatlantic.com/magazine/archive/2014/06/the-case-for-reparations/361631/ (Accessed on 5 March 2014).

Connolly NDB, Winling L, Nelson R, and Marciano R (2018) Mapping inequality: 'Big data' meets social history in the story of redlining. In Gregory I, DeBats D, Lafreniere D (eds) The Routledge Companion to Spatial History. London: Taylor \& Francis.

Connolly NDB (2017) Black and woke in capitalist America: Revisiting Robert Allen's Black Awakening... for new times' sake. Items: Insights from the Social Sciences, https://items.ssrc.org/reading-racial-conflict/black-and-woke-in-capitalist-americarevisiting-robert-allens-black-awakening-for-new-times-sake/ (Accessed on 5 October 2019).

Dawson M (2016) Hidden in plain sight: A note on legitimation crises and the racial order. Critical Historical Studies (Spring 2016): 143-161.

Department of Housing and Development (1972) Transmittal notice. 11 December 1972. https://www.hud.gov/sites/documents/42601HSGH.PDF.

Department of Housing and Urban Development (1973) A Study of Property Taxes and Urban Blight. Washington, DC: US Government Printing Office.

Federici S (2004) Caliban and the Witch: Women, the Body, and Primitive Accumulation. Brooklyn: Autonomedia.

Fraser N (2016) Expropriation and exploitation in racialized capitalism: A reply to Michael Dawson. Critical Historical Studies (Spring 2016): 163-78.

Freund D (2007) Colored Property: State Policy and White Racial Politics in Suburban America. Chicago: University of Chicago Press.

Garvin EC, Cannuscio CC, Branas CC (2013) Greening vacant lots to reduce violent crime: a randomized controlled trial. Injury Prevention 19: 198-203.

George S, Hendley A, Macnamara J, Perez J and Vaca-Loyola A (2019) The Plunder of Black Wealth in Chicago: New Findings on the Lasting Toll of Predatory Housing Contracts. Durham, NC: Samuel DuBois Cook Center on Social Equity at Duke University. 
Gordon G and Swanson A (1976) Institutional cancer eats away at ghetto. Chicago Daily News, 7 December.

Gilmore RW (2002) Fatal couplings of power and difference: Notes on racism and geography. The Professional Geographer, 54(1): 15-24.

Grodzinski A (2019) Planting refuge: Greening and violence prevention [Webinar]. In: Center for Community Progress Webinar Series, 25 April.

Harris C (1993) Whiteness as property. Harvard Law Review 106(8): 1707-1791.

Haswell A and Levine BB (1984) The Illinois Land Trust: A fictional best seller. DePaul Law Review 33(2): 277-321.

Harvey D (1974) Class-monopoly rent, finance capital and the urban revolution. Regional Studies 8(3-4): 239-255.

Harvey D (1982) The Limits to Capital. Oxford: Blackwell.

Howell J and Korver-Glenn E (2018) Neighborhoods, race, and the twenty-first-century housing appraisal industry. Sociology of Race and Ethnicity 4(4): 473-490.

Howell J and Korver-Glenn E (2020) The increasing effect of neighborhood racial composition on housing values, 1980-2015. Social Problems doi.org/10.1093/socpro/spaa033.

Immergluck D and Wiles M (1999) Two Steps Back: The Dual Mortgage Market, Predatory Lending, and the Undoing of Community Development. Chicago: Woodstock Institute.

Institute for Housing Studies at DePaul University (2021) Foreclosure filings per 100 residential properties. https://www.housingstudies.org/data-portal/browse/?indicator=foreclosures100-residential-parcel\&view_as=view-table (Accessed on 26 February 2021).

Kahrl A (2017) Investing in distress: Tax delinquency and predatory tax buying in urban America. Critical Sociology 43(2): 199-219.

Kelly K (2007) The high price of home ownership. The Chicago Reporter, 1 December. https://www.chicagoreporter.com/high-price-home-ownership/ (Accessed on 10 October 2019).

Kondo M, Hohl B, Han S, Branas C (2016) Effects of greening and community reuse of vacant lots on crime. Urban Studies 53(15): 3279-3295.

Light J (2011) Discriminating appraisals: cartography, computation, and access to federal mortgage insurance in the 1930s. Technology and Culture 52(3): 485-522. 
Lyons A, Bremer F, and School of Urban Sciences, University of Illinois at Chicago Circle (1979) Relative Tax Burdens in Black and White Neighborhoods of Cook County. School of Urban Sciences, University of Illinois at Chicago Circle, 24 April.

Mallach A (2018) The Empty House Next Door: Understanding and Reducing Vacancy and Hypervacancy in the United States. Cambridge: Lincoln Institute of Land Policy.

Marx, K (1991) [1894] Capital: Volume III. Trans. D. Fernbach. London: Penguin.

Melamed J (2015) Racial capitalism. Critical Ethnic Studies, 1(1): 76-85.

O’Keefe J (2018) Ideas to action: Vacant land reuse project design, planning, and implementation [Webinar]. In: Center for Community Progress Webinar Series, 22 March.

Pulido L (2016) Flint, environmental racism, and racial capitalism. Capitalism Nature Socialism 27(3): 1-16.

Ranganathan M (2016) Thinking with Flint: Racial liberalism and the roots of an American water tragedy. Capitalism Nature Socialism 27(3): 17-33.

Robinson C (1983) Black Marxism: The Making of the Black Radical Tradition. London: Zed Press.

Safransky S (2014) Greening the urban frontier: Race, property, and resettlement in Detroit. Geoforum, 54: 237-248.

Safransky S (2016) Rethinking land struggle in the post-industrial city. Antipode 49(4): 10791100.

Satter B (2009) Family Properties: How the Struggle Over Race and Real Estate Transformed Chicago and Urban America. New York: Holt.

Sing E (2018) ReClaim ambassadors: Empowering residents through vacant lot projects [Webinar]. In: Center for Community Progress Webinar Series, 26 July.

Smith N (1996) The New Urban Frontier: Gentrification and the Revanchist City. New York: Routledge.

Taylor KY (2012) Back story to the neoliberal moment: Race taxes and the political economy of black urban housing in the 1960s. Souls 14(3-4): 185-206.

Taylor KY (2019) Race for Profit: How Banks and the Real Estate Industry Undermined Black Homeownership. Chapel Hill: University of North Carolina Press.

The Chicago Reporter (2012) The High Price of Homeownership: A Chicago Reporter Investigation on the Policy Implications of High-Cost Loans in the Chicagoland Region. 
https://ideas.time.com/wp-content/uploads/sites/5/2012/01/chicago-reporter.pdf (Accessed on 10 October 2019).

Ture K and Hamilton C (1992) [1967] Black Power: The Politics of Liberation in America. New York: Vintage Books.

Woodstock Institute (2019) Residential vacancy rate by community area. https://woodstockinst.org/data-portal/housing/ (Accessed on 15 September 2019).

Wyly E, Moos M, Hammel D and Kabahizi E (2009) Cartographies of race and class: mapping the class-monopoly rents of American subprime mortgage capital. International Journal of Urban and Regional Research 33(2): 332-354.

Zaimi R (2020) Making real estate markets: The co-production of race and property value in early-20th-century appraisal. Antipode 52(5): 1539-1559. 